\title{
Modification of Soil Properties for Blueberry (Vaccinium Corymbosum L.) Cultivation
}

\author{
Jana Apse*, Aldis Karklins \\ Institute of Soil and Plant Sciences, LLU
}

\begin{abstract}
Highbush blueberries are a relatively new crop in Latvia raising interest in farmers who wish to diversify their commercial horticultural activities. It is considered that soil properties are one of the possible shortcomings limiting establishment of high-productive plantations in areas where soil reaction is close to neutral. The research objective was to test the main soil characteristics in a commercial highbush blueberry plantation where initial soil properties were changed as a result of soil modification (deep tillage, peat additions) before planting of bushes and afterwards maintained (mulching with acid peat and sawdust) periodically. The research was carried out in 2011 - in a farm where the blueberry plantation had been established seven years ago. The experimental plots were arranged on a complex slope, by choosing different parts of terrain. Soil - Haplic Cambisol, sandy loam, formed on a low calcareous moraine. Original topsoil's reaction was $\mathrm{pH} \mathrm{KCl} \mathrm{5.37.} \mathrm{Five}$ experimental plots, each consisting of seven bushes, were set up. Research showed that modification of topsoil significantly changed the physical and agrochemical properties of soil. Soil bulk density reduced, porosity and soil aeration increased. Sphagnum peat $(\mathrm{pH} \mathrm{KCl} \mathrm{3.0)}$ as a soil modifier allowed efficiently reducing the soil reaction at the soil root zone and provided an optimal environment for blueberries. Soil properties were not the determinant factor that limited establishment of a productive blueberry plantation. Soil properties adjusted accordingly to the requirements of highbush blueberry gave the possibility of establishing plantations also in typical mineral soils that develop on a low calcareous moraine.
\end{abstract}

Key words: Highbush blueberries, cultivation in Latvia, soil properties, plant nutrient diagnosis.

\section{Introduction}

Highbush blueberries are a relatively new crop cultivated in Latvia and raising interest in farmers who are looking for diversification of business activities. The experience obtained from other countries (Haynes \& Swift, 1986; Austin \& Bondari, 1992; Smolarz, 2009; Xie \& Wu, 2009) as well as some research done in Latvia (Nollendorfs, 2004; Osvalde, Nollendorfs, Karlsons, \& Pormale, 2011) shows that blueberries have rather specific soil requirements, therefore it is not always possible to find a place where natural soil properties are appropriate. Modification of soil properties (if possible) and site preparation are activities which should be done before blueberries are planted. Importance of that is high, because the highbush blueberries are perennial shrubs growing at the same place up to 50 years without replanting. Therefore site preparation, soil amelioration, cultivar and plant density selection, methods of growing, etc., are items which should be considered very carefully in order to establish a high-productive and long lasting highbush blueberry plantation.
In Latvia, there is no many research data about the influence of soil physical and chemical properties on the development of vegetative and reproductive parts of highbush blueberries, as well as about the methods suitable for modification of soil properties. Therefore, the aim of the present research was to study the influence of soil modification on soil physical properties and fertility characteristics as well as on the development and yield potential of blueberries.

\section{Materials and Methods}

The site and soil characteristics. The research was carried out in a highbush blueberry plantation (established on a 5-7\% south-east slope in 2004) at the farm Bīsnes in Ogre district in 2011. The total acreage of the plantation was 3 ha, planting density - 2000 bushes per ha. Predominant soil Haplic Cambisol (World Reference Base ..., 2006), sandy loam, developed on moraine (Kārkliņš, 2008). The original topsoil reaction $-\mathrm{pH} \mathrm{H}_{2} \mathrm{O} 6.14$ and $\mathrm{pH} \mathrm{KCl}$ 5.37; organic matter content $-25 \mathrm{~g} \mathrm{~kg}^{-1}$.

\footnotetext{
* Corresponding author's email: jana.apse@inbox.lv
} 
Before establishing the plantation, radical improvement (change) of soil properties was done. In 2004 , the bushes were planted in $1.65 \times 3.00-\mathrm{m}$ rows, deep cultivated, and mixed with acid ( $\mathrm{pH} \mathrm{KCl} \mathrm{3.0 \pm 0.3)} \mathrm{sphagnum} \mathrm{peat.} \mathrm{Each} \mathrm{second}$ year, the same kind of peat was used as a mulch to cover a $5-\mathrm{cm}$ layer on the soil surface between the bushes. During summer, 0.7-m wide strips along the bushes were kept free from vegetation, but grasses Lolium perenne L., Phleum pratense L., Festuca pratenis H., and Festuca rubra L. were sown and periodically mown in interrow spaces. In 2007, a drop fertigation system was constructed. The research was performed in five plots located in different positions on a convex slope, representing four different cultivars of highbush blueberries. Each plot consisted of seven fully developed bushes located in one row.

In April 2011, soil sampling was done in each plot and at two depths: $0-20 \mathrm{~cm}$, and $20-40 \mathrm{~cm}$. Two soil profiles in different locations were prepared and described. The following analytical methods were used: $\mathrm{pH}$ - potentiometrically in a $1 M \mathrm{KCl}$ suspension; organic matter for mineral soils - using Tyurin's method, for organic soils by dry combustion; total nitrogen - by Kjeldahl method; plant available phosphorus and potassium in mineral soils - by Egner-Riehm method; PK in organic soils - total concentration after ashing of sample.

Soil physical properties were measured in June and repeated in August. Undisturbed soil samples, using $100 \mathrm{~mL}$ stainless steel cylinders, were collected for the bulk density, porosity and field capacity measurements (Kārkliņš, 2008). Measurements were done in both sites of the plantation: in the lower part (soil profile), and in the upper part (additional site). Two sampling points were chosen in each site: unchanged soil in interrows, and modified substratum in the strip of bushes. Stepwise sampling using $5-\mathrm{cm}$ increments from the soil surface up to the $40-\mathrm{cm}$ depth was applied.

Plant material. Plant leaf samples were collected from each plot two times per season: on July 8 - from previous-year shoots, and on August 5 - from the new shoots. Samples of the most recently fully expanded leaves that were free from disease or other damage were collected, and each sample consisted of 10 leaves from each of the seven plants. Total nitrogen was determined using Kjeldahl method; total phosphorus and potassium were analyzed after ashing - colorimetrically and by flame photometry respectively.
Data processing included computing of partial and multiple correlation as well as $t$ test for evaluation of soil organic matter and reaction change.

\section{Results}

Productivity of blueberries. The yield of blueberries in experimental plots was measured only in 2011. From 2007 to 2010, the overall yield level by varieties was taken from the farmer's records and made 3-5 t ha-1 annually. Due to the extreme winter conditions as well as production periodicity in 2011, berry yield was very modest for many cultivars: 'Bluecrop' in sandy soil $-0.08 \mathrm{t} \mathrm{ha}^{-1}$, in clayey soil $-0.41 \mathrm{t} \mathrm{ha}{ }^{-1}$; 'Northland' $-4.54 \mathrm{t} \mathrm{ha}^{-1}$; 'Duke' $-0.13 \mathrm{t} \mathrm{ha}^{-1}$; and 'Patriot' $-0.38 \mathrm{t} \mathrm{ha}^{-1}$. The research suggests that only yield of the 'Northland' cultivar might be considered comparable with the average long-term yield level. All other cultivars showed a considerably lower yield level than the average.

Soil conditions in the plantation. Soil investigation (morphological observations, sampling, and profile descriptions) showed that soil cover, despite the different topography, was comparatively homogenous without contrasting inclusions. Soils in the plantation could be regarded as typical mineral soils belonging to the automorphic genetic class. At the lower part of the hillside, free carbonates were observed starting from the depth of $100 \mathrm{~cm}$. The soils located at the upper part of the morainic hill had slightly different parent material. Firstly, at the shallow depth $(40 \mathrm{~cm})$, some clayey material (lens) was located, as well as fragments of dolomite were found; therefore the free carbonates were observed there already at the depth of $30 \mathrm{~cm}$. Soil mass movements from the top of the hill to the lower part of the slope (erosion) probably happened when the field was under annual tillage.

Soil physical properties. One of the parameters important for any crop growth is bulk density of substratum. Also in the present plantation, where soil properties in the strips had been changed dramatically, growth media was not the real soil any more but rather substratum. As bulk density is dependent on moisture conditions, sampling was done twice. The parameters of bulk density measured on June 9, when vegetation was fully renewed and moisture conditions were typical for that time of year, are shown in Fig. 1A, but those of August 18, after a relatively rainy period (rainfall in July was $71.2 \mathrm{~mm}$, and at the beginning of August - $98.7 \mathrm{~mm}),-$ in Fig. 1B. 

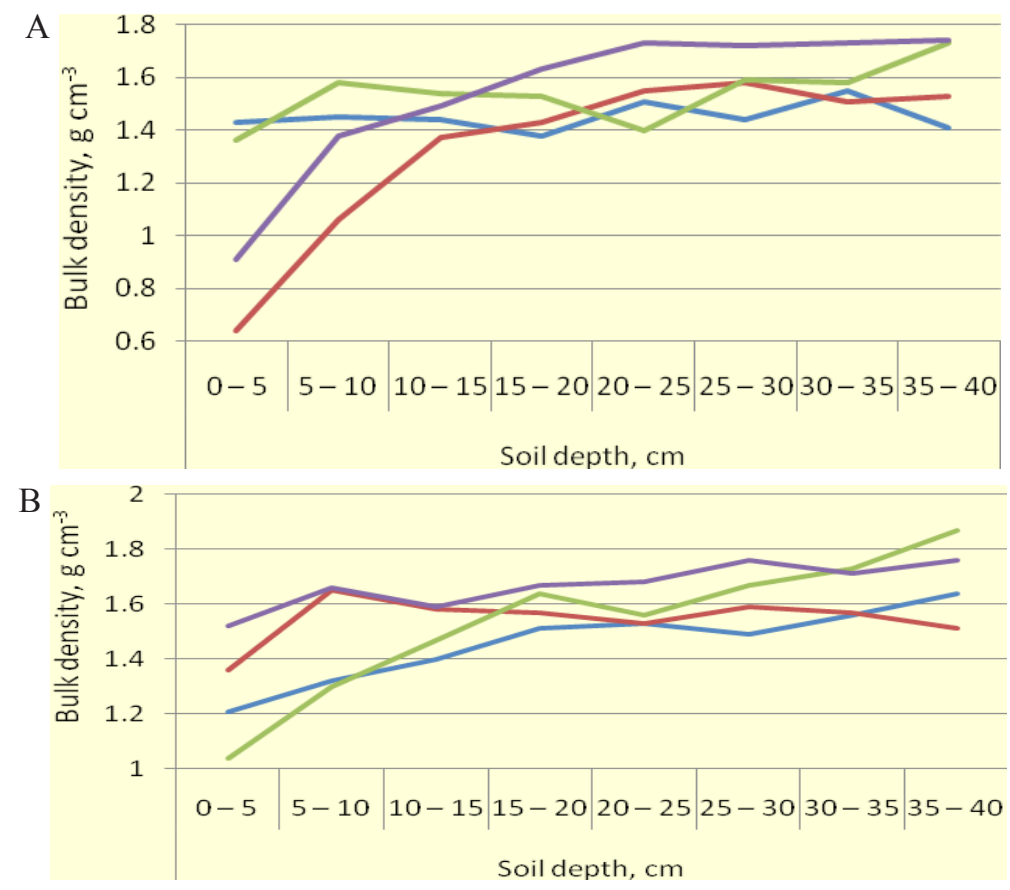

Lower part

unchanged soil

Upper part modified soil

unchanged soil modified soil

Fig. 1. Soil bulk density in both experimental sites, $\mathrm{g} \mathrm{cm}^{-3}$ (A - on June 9; B - on August 18).
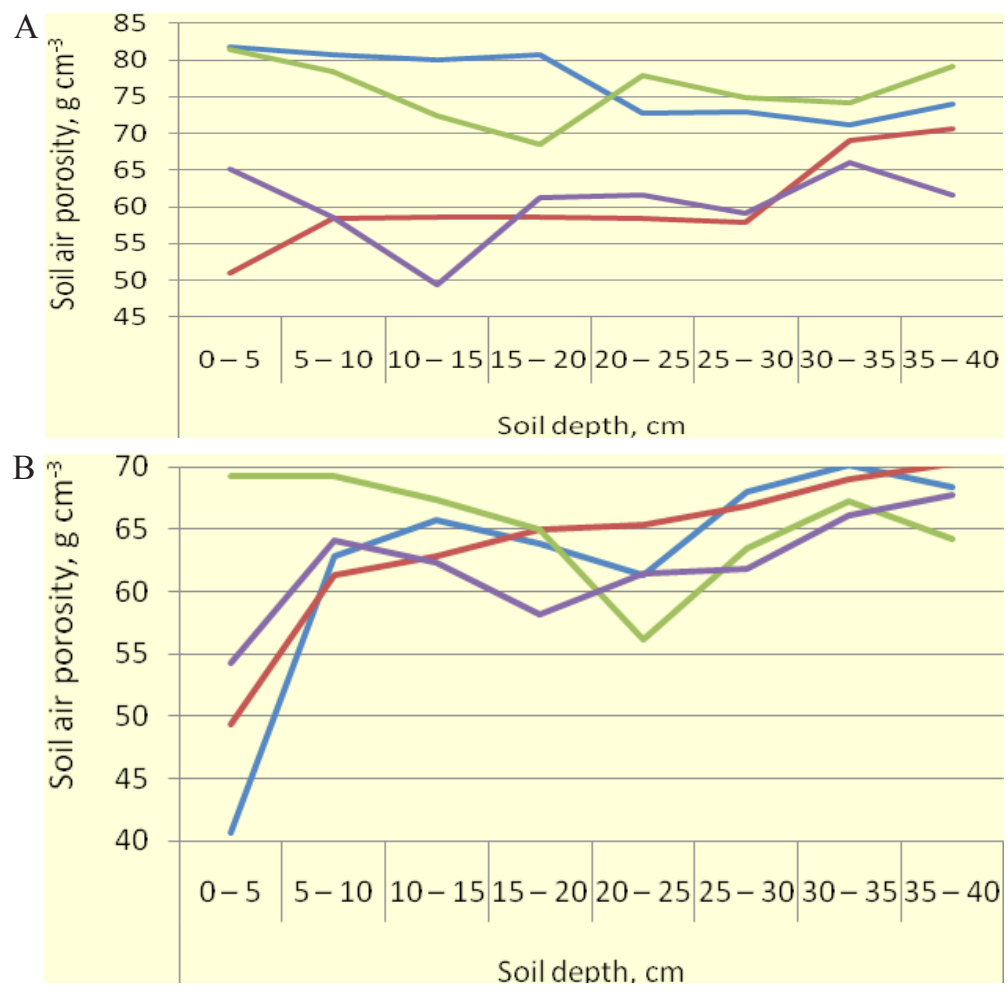

Fig. 2. Soil air porosity in both experimental sites, \% (A - on June 9; B - on August 18) (legend see in Fig. 1). 
Deep tillage and peat additions affected soil bulk density up to $15-20 \mathrm{~cm}$ from the surface, and more radically - in the first $10 \mathrm{~cm}$. Bulk densities in both locations (upper and lower part of slope) for unchanged soil were very similar in all layers, starting from the topsoil and up to $40 \mathrm{~cm}$. Density was around $1.49 \mathrm{~g} \mathrm{~cm}^{-3}$ in June, and $1.50 \mathrm{~g} \mathrm{~cm}^{-3}$ in August. The influence of soil modification on air porosity is shown in Fig. 2 (A - June, and B - August), on field capacity of experimental sites - in Fig. 3 (A - June, and B - August).
Field capacity had close positive correlation with air porosity. Therefore the upper layer of the modified substratum had both higher field capacity (better water holding and storage ability) and better aeration. The latter is important not only for providing good air exchange between soil and atmosphere but also for fast excess water infiltration during rainstorm or snow melting. In a situation when drip irrigation system was operating and water supply could be adjusted according to the actual needs, physical properties of the substratum were

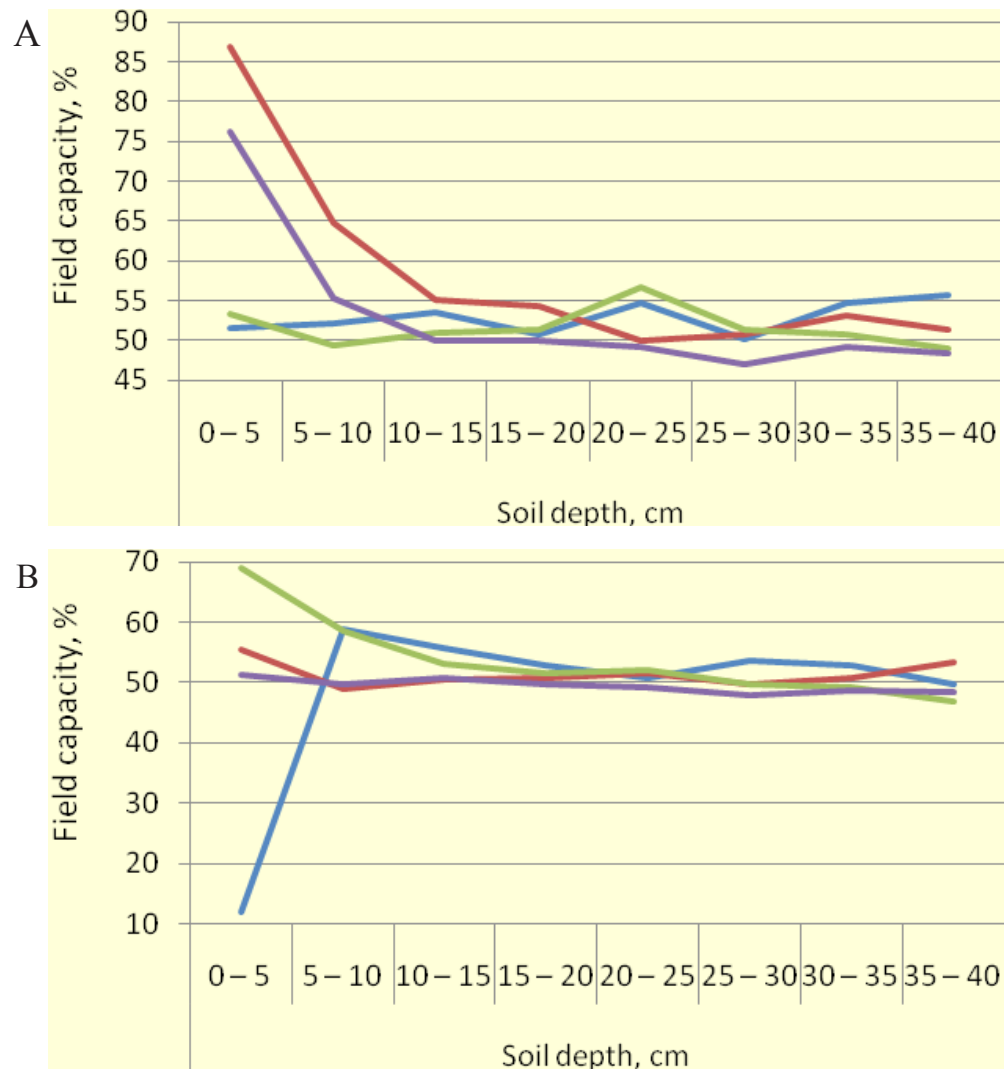

Fig. 3. Soil field capacity in both experimental sites, \% (A - on June 9; B - on August 18) (legend see in Fig. 1).

\section{Soil agrochemical properties after soil modification}

\begin{tabular}{|c|c|c|c|c|c|c|c|c|}
\hline \multirow{2}{*}{$\begin{array}{l}\text { Position on } \\
\text { landscape, } \\
\text { and variety }\end{array}$} & \multicolumn{4}{|c|}{ 0-20 cm topsoil } & \multicolumn{4}{|c|}{$20-40 \mathrm{~cm}$ subsoil } \\
\hline & $\begin{array}{l}\text { OM, } \\
\mathrm{g} \mathrm{kg}^{-1}\end{array}$ & $\begin{array}{c}\mathrm{N}^{*} \\
\mathrm{~g} \mathrm{~kg}^{-1}\end{array}$ & $\begin{array}{c}\mathrm{P} \\
\mathrm{mg} \mathrm{kg}^{-1}\end{array}$ & $\begin{array}{c}\mathrm{K}, \\
\mathrm{mg} \mathrm{kg}^{-1}\end{array}$ & $\begin{array}{l}\mathrm{OM}, \\
\mathrm{g} \mathrm{kg}^{-1}\end{array}$ & $\begin{array}{c}\mathrm{N}^{*} \\
\mathrm{~g} \mathrm{~kg}^{-1}\end{array}$ & $\begin{array}{c}\mathrm{P} \\
\mathrm{mg} \mathrm{kg}^{-1}\end{array}$ & $\begin{array}{c}\mathrm{K}, \\
\mathrm{mg} \mathrm{kg}^{-1}\end{array}$ \\
\hline 1U 'Bluecrop' & 296.8 & 2.73 & $584^{*}$ & $498 *$ & 25.8 & 0.98 & $85^{*}$ & $64 *$ \\
\hline 2U 'Bluecrop' & 38.2 & 1.43 & $116^{* *}$ & $106 * *$ & 13.2 & 0.67 & $31 * *$ & $65 * *$ \\
\hline 3U 'Northland' & 43.9 & 1.59 & $124 * *$ & $80 * *$ & 22.6 & 0.88 & $74 * *$ & $75 * *$ \\
\hline 4L 'Duke' & 214.3 & 3.72 & $536^{*}$ & $398 *$ & 26.3 & 1.09 & $140 *$ & $105^{*}$ \\
\hline 5L 'Patriot' & 167.1 & 2.72 & $266^{*}$ & $224 *$ & 23.0 & 0.91 & $112^{*}$ & $74 *$ \\
\hline
\end{tabular}


evaluated as adequate for good development of highbush blueberries.

Agrochemical properties. Soil reaction at the upper 0-40-cm layer was acid ( $\mathrm{pH} \mathrm{KCl} \mathrm{2.95-5.75)}$ in the experimental plots. Topsoil was more acidic than the subsoil due to the periodical application of mulch - acid ( $\mathrm{pH} \mathrm{KCl} \mathrm{3.0 \pm 0.3)} \mathrm{sphagnum} \mathrm{peat}$ plus sawdust. Therefore, for cultivar 'Bluecrop' (Variant 1) at the depth of $0-20 \mathrm{~cm}$, soil reaction reached even $\mathrm{pH} \mathrm{KCl} 2.95$, which actually might be considered too acid for blueberries. In such a situation, calcium uptake for plants is very limited, i.e., calcium is practically lacking (absolute deficit). If blueberries receive water soluble calcium without raising the reaction (e.g. by fertilisation), the negative effect of low reaction can be minimised.

Other parameters of soil agrochemical properties are shown in Table 1. The experimental plots were located at different positions on the hillside, therefore the plots located on the upper part of hillside are marked with $\mathrm{U}$, and plots located on the lower part - with L.

The use of acid peat significantly lowered the soil $\mathrm{pH}$. The initial soil reaction was $\mathrm{pH} \mathrm{KCl} \mathrm{5.13-5.37,}$ but after modification it decreased to 2.95-5.28. This effect was observed up to $40-45 \mathrm{~cm}$ from the soil surface, depending on the thickness of mulch layer. Gradually, with the aging of mulch layer, the effect of acidification decreased, e.g., in the 2nd plot of 'Bluecrop' variety, $\mathrm{pH} \mathrm{KCl}$ was 5.40-5.75. In the commercial plantation, renewal of mulch was carried out periodically once per three years, and only one third of the bushes received fresh peat additions annually. Soil layer deeper than $45 \mathrm{~cm}$ was not affected by acid peat and soil reaction remained the same.

Variations among $\mathrm{pH}$ values $(\mathrm{S}, \%)$ were rather high: in topsoil $-4.44 \%$, but in subsoil - up to $30.02 \%$. Due to the variability of peat properties, age

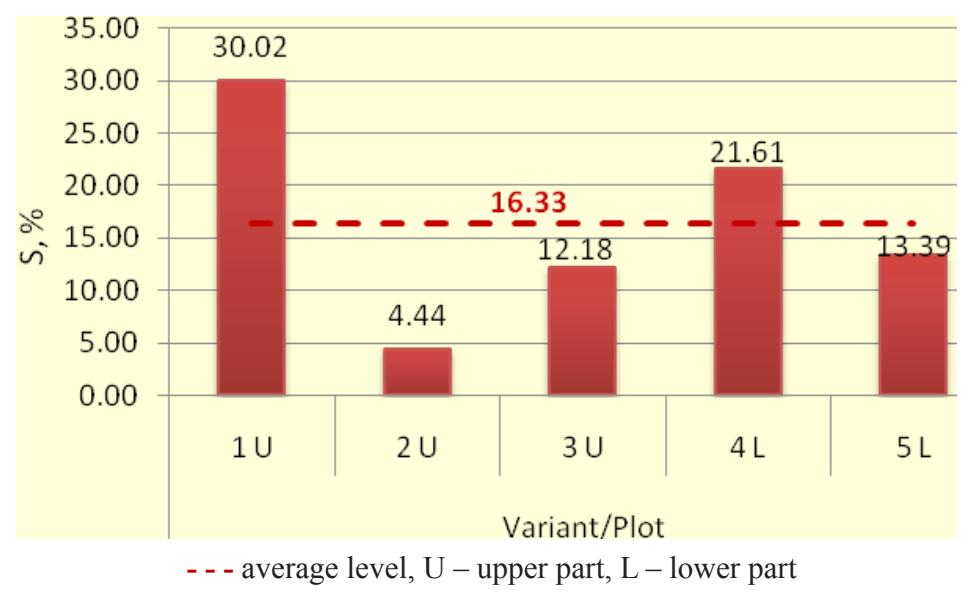

Fig. 4. Differences in soil $\mathrm{pH} \mathrm{KCl}$ between topsoil and subsoil (coefficients of variation, $\mathrm{S}, \%$ ).

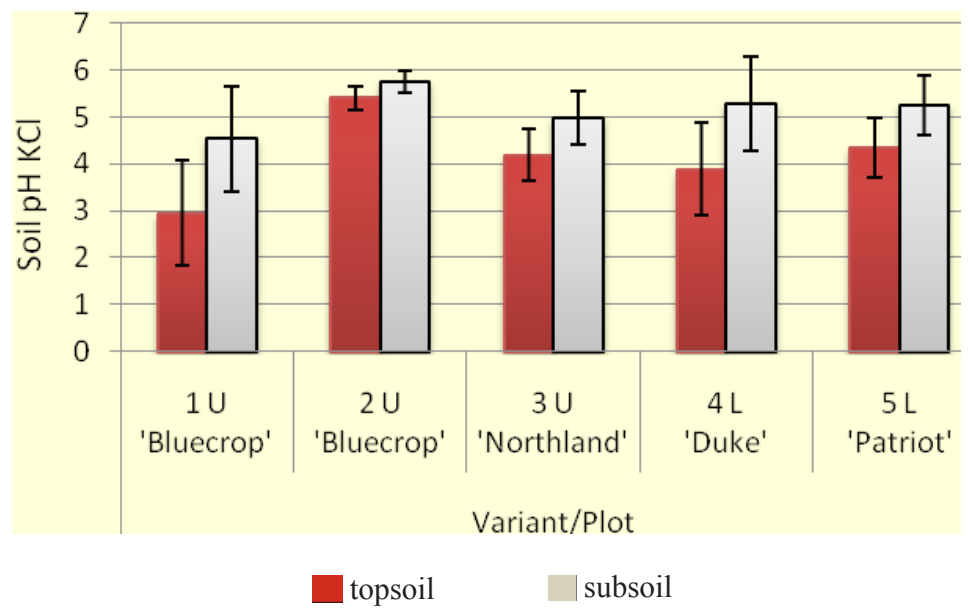

Fig. 5. Differences in soil pH $\mathrm{KCl}$ between topsoil $(0-20 \mathrm{~cm})$ and subsoil $(20-40 \mathrm{~cm})$. 
of mulch, as well as differences in soil properties, some heterogeneity within the soil reaction in the plantation occurred. Standard deviation of $\mathrm{pH}$ mean values was observed within the range of \pm 1.12 (1st plot), \pm 0.25 (2nd plot), \pm 0.56 (3rd plot), \pm 0.99 (4th plot), and \pm 0.64 (5th plot) (Figs 4 and 5). Correlation analysis showed that a negative $(\mathrm{r}=-0.75)$ relationship between subsoil $(20-40 \mathrm{~cm}) \mathrm{pH}$ and organic matter content existed, which means that in locations where soil $\mathrm{pH}$ was lower, mineralization of organic matter (peat additions) was slower. Using $t$ test $\left(\mathrm{t}_{\text {fact. }}<\mathrm{t}_{0.05}\right)$, it was established that the content of organic matter and total nitrogen in the soil did not significantly influence the soil $\mathrm{pH}$ value. On average, soil reaction for the whole plantation was $\mathrm{pH} \mathrm{KCl}$ 4.15 in 2011, compared to the $\mathrm{pH} \mathrm{KCl} 4.80$ in 2006. This means that periodical mulching may lower $\mathrm{pH}$ by maintaining it within the range optimal for highbush blueberries.

Organic matter content in topsoil varied significantly due to the application of mulch. Soil mulching was done periodically each second year. Therefore, some experimental plots received fresh mulch, but some - mulch from the previous year. The difference between topsoil and subsoil in terms of the organic matter and plant nutrient content was significant -13.2-296.8 $\mathrm{g} \mathrm{kg}^{-1}$.

Nutrient accumulation in the upper part of substratum occurred due to fertiliser application. This layer can be regarded as nutrient-rich, which probably stimulated development of blueberry roots close to the soil surface. But, generally, both the upper and lower part of the substratum can be evaluated as containing an adequate amount of plant nutrients if the reference is made related to other small berry shrubs grown in Latvia. The effect of mulching in relation to the increase in organic matter in the soil was observed up to $40 \mathrm{~cm}$; deeper in the modified as well as in the initial soil, the organic matter content was similar.
A statistically significant $\left(\mathrm{t}_{\text {fact. }}<\mathrm{t}_{0.05}\right)$ correlation $(\mathrm{r}=0.96)$ was observed between soil organic matter content and total nitrogen concentration in subsoil.

Plant nutrient uptake. Plant nutrient concentration in leaves (the previous-year and current-year shoots) was analysed mainly in order to use this parameter for plant nutrition diagnosis (Table 2). The obtained results were compared with the data found in the literature (Hart, Strik, White, \& Yang, 2006; Nolendorfs, Karlsons, \& Čekstere, 2007). Some variations occurred between cultivars and type of shoots. As the blueberries were treated with fertilisers according to the full scheme (based on the long-term experience) in the years 2010 and 2011, it can be considered that crops received all necessary nutrients.

\section{Discussion}

Normally, blueberries produce a rather stable yield without considerable fluctuations year by year. However, in 2011, after a relatively productive 2010 season, the berry harvest was modest. In spring 2011, the plants suffered from a thick snow cover, which formed already in November 2010 on unfrozen soil. Thick snow and ice-crusted ground damaged the plants, therefore a large part of them were trimmed out in the following spring. Only one cultivar, 'Northland', produced a rather good yield, which was comparable with the average yield level obtained in the experimental farm before.

During establishment of the plantation, soil properties became more heterogenic. For the growth and development of highbush blueberries, the conditions within the space where the plants' roots are located (e.g. in plant strips) have the highest importance. According to the publications (Pormale, Osvalde, \& Nollendorfs, 2009), the main root

Table 2

The concentration of plant nutrients in dry matter of blueberry leaves, $\mathbf{g ~ k g}^{-1}$

\begin{tabular}{lcccccc}
\hline \multirow{2}{*}{$\begin{array}{c}\text { Position on } \\
\text { landscape, } \\
\text { and variety }\end{array}$} & $\mathrm{N}$ & $\mathrm{P}$ & $\mathrm{K}$ & $\mathrm{N}$ & $\mathrm{P}$ & $\mathrm{K}$ \\
\cline { 2 - 6 } Previous year shoots on July 8 & & & & & \\
\hline 1U 'Bluecrop' & 9.64 & 0.99 & 3.69 & 10.28 & 1.49 & 3.99 \\
\hline 2U 'Bluecrop' & 11.33 & 1.02 & 4.06 & 11.05 & 1.51 & 3.87 \\
\hline 3U 'Northland' & 8.59 & 0.80 & 2.21 & 9.78 & 1.20 & 2.83 \\
\hline 4L 'Duke' & 9.78 & 1.08 & 3.62 & 10.33 & 1.47 & 3.34 \\
\hline 5L 'Patriot' & 9.95 & 1.63 & 3.85 & 9.94 & 1.19 & 3.76 \\
\hline
\end{tabular}


distribution (around $90 \%$ by mass) of blueberries is within $1 \mathrm{~m}$ of the plant strip horizontally, and up to the depth of $40 \mathrm{~cm}$ vertically. Therefore, the main attention related to soil conditioning, $\mathrm{pH}$ adjustment, tillage, and fertiliser application should be paid there. Interrows are occupied by grass and used for traffic and for management of blueberry bushes, therefore soil conditions and soil fertility are less important there.

Our experimental plantation of highbush blueberries was established on typical mineral soil formed on low calcaric till. Whereas numerous researchers (Li, Tang, Wulin, \& Zang, 2006; Ancu, Iancu, Mladin, \& Ancu, 2010; Vano, Matsushima, Tang, \& Inubushi, 2011) suggest that such soils are not suitable for highbush blueberries due to the high $\mathrm{pH}$, low organic matter content, high bulk density, etc. Therefore, if other soils more suitable for blubbery cultivation are not available in the vicinity, some modification of soils' initial properties might be necessary. These activities were performed at our experimental site using deep $(40 \mathrm{~cm})$ ploughing in strips where bushes were planted as well as incorporation of acid sphagnum peat and periodic covering of bush strips with acid peat and sawdust mulch. Using such technique, soil conditions around the blueberries were transformed and, together with irrigation and fertilizer use, provided good conditions for plant growth. In such a way, soil is no longer a limiting factor for establishment of highbush blueberry plantations in Latvia.

Bulk density of soil was rather high and showed compaction effect, which is common in places where soil tillage has not been used for several years. Modification effect was significant and affected the top layer up to $15 \mathrm{~cm}$ deep (Fig. 1).

Field capacity is a parameter showing the volume of water the soil is able to retain. This means that at a higher field capacity, the soil or substratum can hold more plant available water in periods when precipitation is absent. As highbush blueberry is a water consuming plant, it should be provided with sufficient water supply throughout the growing season, including periods with high temperature and lack of precipitation.

In our experiment, the use of sphagnum peat significantly changed the soil physical properties (Fig. 3). Soil bulk density decreased, but air porosity (aeration) increased (Figs 1 and 2), which positively influenced the growth of highbush blueberries, since stimulation of air exchange, increase in water infiltration, and the resulting facilitation of microbiological processes provided better environment for crop development. Rapid drainage of excess water was compensated by higher field capacity as well as by the installed drip irrigation, providing plants with water and nutrients simultaneously. Irrigation installation is an important component for soil modification, because use of peat decreases soil capillary porosity and subsequently water supply from the deepest layers.

Many researchers (Vano, Matsushima, Tang, \& Inubushi, 2011; Smagula, McGovern, 2012) point out the importance of soil (substratum) reaction for highbush blueberry cultivation. It is considered that this crop requires a moderately acid growth media, i.e. $\mathrm{pH} \mathrm{KCl}<5.5$ (Hancock, 2009; Xie \& Wu, 2009; Paal et al., 2011). In many cases, this is the limiting factor for establishment of plantations in mineral soils that are not acid either naturally or after liming. The USA, Canada, and Poland are countries where highbush blueberries are widely cultivated, therefore advanced experience has been accumulated there. The researchers from these countries (Haynes \& Swift, 1985; Sanderson, Carterl, \& Ivany, 1995; Ochmian, Grajkowski, Mikiciuk, Ostrowska, \& Chelpinski, 2009) consider that the optimal soil reaction $\mathrm{pH} \mathrm{KCl}$ for highbush blueberries is 4.2-4.8. In very low $\mathrm{pH}$ $\mathrm{KCl}$ environment (lower than 3.4), plants suffer from $\mathrm{Ca}$ deficiency; if reaction becomes less acid ( $\mathrm{pH} \mathrm{KCl} \mathrm{3.4-3.8),} \mathrm{plants} \mathrm{gradually} \mathrm{recover} \mathrm{but}$ productivity (yield of berries) is very low (Hart, Strik, White, \& Yang, 2006; Hancock, 2009). Therefore, it is considered that $\mathrm{pH} \mathrm{KCl} 3.8$ is the lowest possible (reasonable) level for blueberry production (Haynes \& Swift, 1985; Hancock, 2009).

Similar research results have been obtained also in Latvia. A. Ripa has reported that growing highbush blueberries under Latvia's conditions, the optimal soil reaction is $\mathrm{pH} \mathrm{KCl} 3.8-4.8$ (excluding rabbiteye blueberries, which require a higher pH KCl level - around 5.8) (Ripa, 1992). Similar recommendations have been given also by Polish researcher K. Smolarz (2009), who is involved in the breeding of new blueberry varieties. High reaction $(\mathrm{pH} \mathrm{KCl}>5.2)$ reduces mobility of plant available micronutrients $\mathrm{Fe}, \mathrm{Zn}$, and $\mathrm{Cu}$, therefore relative deficiency might be observed (Haynes \& Swift, 1985; Osvalde, Nollendorfs, Karlsons, \& Pormale, 2011). In our experiment, the use of acid ( $\mathrm{pH} \mathrm{KCl} \mathrm{3.0 \pm 0.3)} \mathrm{sphagnum} \mathrm{peat}$ was an efficient way to decrease soil reaction in blueberry root zone, to increase the organic matter content in soil, and partly also to serve as 
a tool for depression of weed growth between the bushes.

Evaluation of plant nutrient concentrations in soil (substratum) for highbush blueberries is rather complicated because of the small number of research data obtained using one standardized analytical method and experiments performed in compatible conditions. If this is overcome, some correlation criteria could be possible to develop. Currently, highbush blueberry growers in Latvia use at least two kinds of analytical procedures to evaluate the soil fertility. The analytical methods for highbush blueberries offered by the laboratory of the State Plant Protection Service are the same as for field crops (used in the present research), but they lack any interpretation criteria relevant for highbush blueberries. Officially, all growers who are involved in the Integrated Horticulture Scheme in Latvia should test the soil in their plantations using the above-mentioned methods periodically.

Another laboratory (in Salaspils) that offers soil testing for horticultural crops uses completely different analytical methods (soil extraction with $1 M \mathrm{HCl}$ for determination of all nutrients). The data obtained there are not compatible with the data obtained at the aforementioned laboratory; at the same time, the research data for interpretation of analytical results are more advanced in the Salaspils laboratory (Nollendorfs, Karlsons, \& Čekstere, 2007). Therefore, it is still an open question to decide about a common scheme for soil fertility evaluation, as well as to accumulate sufficient amount of research data to be able to develop criteria for their assessment. Some ideas for soil test data interpretation using Egner-Riehm method might be borrowed from the publications (Hendershot, Lande, \& Duguette, 2007; KondratowiczMaciejewska \& Kobierski, 2011).

Another method to evaluate the crop nutrition status is to analyse the growing parts of a plant. Compared with soil (substratum) analysis, this method has some advantages. The concentration of plant nutrients in a growing plant's tissues shows whether the plant is or is not able to absorb the ions from soil solution and whether these ions are ready for all metabolic processes in the plant (Marschner, 1995). Chemical procedures used to find this concentration are not important, and compatibility problems are less evident. The only steps which should be harmonised are sample preparation and selection of plant parts used for analysis. Therefore, comparison of the data obtained with the data from the literature is more possible and applicable.

The results obtained in our research were compared with the data found in the literature, where the optimal concentration of plant nutrients in leaves is reported to be $17-20 \mathrm{~g} \mathrm{~kg}^{-1} \mathrm{~N}, 2.0-4.0 \mathrm{~g} \mathrm{~kg}^{-1} \mathrm{P}$, and 4.1-7.0 $\mathrm{g} \mathrm{kg}^{-1} \mathrm{~K}$ (Hart, Strik, White, \& Yang, 2006; Nolendorfs, Karlsons, \& Čekstere, 2007). If these criteria are considered as the reference point, the plant nutrient concentration in plants grown in the experimental plots should be evaluated as inadequate. The full scheme of blueberry fertilisation, including all necessary materials and applications, was done in 2011 (as well as in 2010) in our research. This scheme has been successfully used in the plantation already for several years, therefore it is disputable whether plant nutrient inputs were too small.

Some researchers (Burkhard, Lynch, \& Percival, 2010) point out that the weeds might cause nitrogen deficiency in crops, because they decrease the mineral nitrogen content in soil by $71 \%$. As in blueberry plantations the weeds grow in rows between bushes and also grasses with well developed rooting system located in interrows compete with blueberries, some more literature studies and field research should be done to find the correct criteria relevant for similar soil and climate conditions.

Too little research has been done in Latvia concerning optimum nutrient concentration in soil and in the vegetative parts of highbush blueberries, therefore the issue remains topical and such data are important for fertilization planning.

\section{Conclusion}

The research results showed that soil conditions are not the determinant that limits productive establishment of highbush blueberry plantations in Latvia. After modification of soil properties, plantations could be established also in typical mineral soils developed on a low calcareous moraine. The use of acid ( $\mathrm{pH} \mathrm{KCl} \mathrm{3.0 \pm 0.3)} \mathrm{sphagnum} \mathrm{peat}$ moss as a soil modifier allows efficiently reducing soil reaction at root zone, as well as ensures an optimal environmental reaction for highbush blueberries. Sphagnum peat moss and sawdust mulch significantly influenced the soil physical characteristics: soil bulk density reduced, and porosity and soil aeration increased. This can be considered a positive effect 
since aeration and water infiltration increase and microbiological processes are favoured; however, an irrigation system is necessary, because the capillary porosity decreases.

\section{References}

1. Ancu, I., Iancu, M., Mladin, P., \& Ancu, S. (2010). The planting effects on some growth characteristics of seven blueberry cultivars. Bulletin of University of Agricultural Sciences and Veterinary Medicine Cluj-Napoca Horticulture, 67(1), 91-95.

2. Austin, M.E., \& Bondari, K. (1992). Response of established rabbiteye blueberry to soil amendments and fertilizers. Journal of Small Fruit and Viticulture, 1(1), 27-37.

3. Burkhard, N., Lynch, D., \& Percival, D. (2010). Effects of pine-needle and compost mulches and weeds on nitrogen dynamics in an organically managed highbush blueberry field. Acta Horticulturae, 873(9), 253-260.

4. Hancock, J. (2009). Highbush blueberry breeding. Agronomijas Vēstis, 12, 35-38.

5. Hart, G., Strik, B., White, L., \& Yang, W. (2006). Nutrient management for blueberries in Oregon. Oregon State University Extension Service.

6. Haynes, R.J., \& Swift, R.S. (1985). Growth and nutrient uptake by highbush blueberry plants in a peat medium as influenced by $\mathrm{pH}$, applied micronutrients and mycorrizal inoculation. Scientia Horticulturae, 27(3-4), 285-294.

7. Haynes, R.J., \& Swift, R.S. (1986). Effect of soil amendments and sawdust mulching on growth, yield and leaf nutrients of highbush bluberry plants. Scientia Horticulturae, (119), 41-48.

8. Hendershot, W.H., Lande, H., \& Duquette, M. (2007). Soil reaction and exchangeable acidity. In M.R. Carter \& E.G. Gregorich (Eds), Soil Sampling and Methods of Analysis (2nd ed., pp. 171-178). CRC Press.

9. Kārklinş̌š, A. (2008). Augšņu diagnostika un apraksts. Jelgava: LLU.

10. Kondratowicz-Maciejewska, K., \& Kobierski, M. (2011). Content of available magnesium, phosphorus and potassium forms in soil exposed to various crop rotation and fertilization. Journal of Elementology, 16(4), 543-553.
11. Li, Y., Xuendong, T., Lin, W., \& Zang, Z. (2006). Effect of organic material on soil properties, plant growth, leaf photosynthesis, nutrient uptake and mycorrhizal infection of blueberries. Acta Horticulturae, 715, 375-380.

12. Marschner, H. (1995). Mineral nutrition of higher plants (2nd ed.). London, San Diego, New York: Academic Press.

13. Nollendorfs, V. (2004). Augsto krūmmelleṇu prasības pēc augsnes un mēslojuma. AgroPols, $12,8-10$.

14. Nollendorfs, V., Karlsons, A., \& Čekstere, G. (2007). Krūmmelleņu mēslošana minerālaugsnēs. Dārzs un Drava, 1, 26-29.

15. Ochmian, I., Grajkowski, J., Mikiciuk, G., Ostrowska, K., \& Chelpinski, P. (2009). Mineral composition of high blueberry leaves and fruits depending on substrate type used for cultivation. Journal of Elementalogy, 14(3), 509-516.

16. Osvalde, A., Nollendorfs, V., Karlsons, A., \& Pormale, J. (2011). Dzērveņu un krūmmelleņu minerālā barošanās. Agrotops, 3, 62-64.

17. Paal, T., Starast, M., Noormets-Sanski, M., Vool, E., Tasa, T., \& Karp, K. (2011). Influence of liming and fertilization on lowbush blueberry in harvested peat field condition. Scientia Horticulturae, 130, 157-163.

18. Pormale, L., Osvalde, A., \& Nollendorfs, V. (2009). Comparison study of cultivated highbush and wild blueberry nutrient status in producing plantings and woodlands, Latvia. Agronomijas Vèstis, 12, 80-87.

19. Ripa, A. (1992). Dzērvenes, zilenes, brüklenes dārzā. Rīga: Avots.

20. Sanderson, K.R., Carter, M.R., \& Ivany, J.A. (1996). Effects of gypsum on yield and nutrient status of native lowbush blueberry. Canadian Journal of Plant Science, 76, 361-366.

21. Smagula, J.M., \& McGovern, K.B. (2012). Effects of gypsum on nutrient uptake, growth and yield of the wild lowbush blueberry. Acta Horticulturae, 938(11), 307-314.

22. Smolarz, K. (2009). Short information about the history of the commercial cultivation highbush blueberry in Poland. Agronomijas Vēstis, 12, 119-122.

23. Vano, I., Matsushima, M., Tang, C., \& Inubushi, K. (2011). Effects of peat moss and sawdust compost application on $\mathrm{N}_{2} \mathrm{O}$ emission and $\mathrm{N}$ leaching in blueberry cultivating soils. 
Soil Science and Plant Nutrition, 57(2), 348-360.

24. World Reference Base for Soil Resources 2006: A framework for international classification, correlation and communication. (2006).
World Soil Resources Reports No. 103. Rome: FAO.

25. Xie, Z.S., \& Wu, X.C. (2009). Studies on substrates for blueberry cultivation. Acta Horticulturae, 810, 513-520. 